\title{
DETERMINANT OF COFFE SHOP SERVICE QUALITY IN THE NEW NORMAL ERA, EMPIRICAL EVIDENCE FROM DENPASAR CITY
}

\author{
Putu Saroyini Piartrini \\ Dosen Universitas Udayana \\ royetrini@unud.ac.id
}

\begin{abstract}
ABSTRAK
Pertambahan jumlah coffee shop di kota Denpasar dan keluhan terkait pelayanan coffee shoP di Kota Denpasar menjadi alasan penelitian ini dilakukan. Perbedaan tujuan mengunjungi coffee shop, melahirkan harapan yang berbeda. Memahami kemampuan pelayanan coffee shop dalam memenuhi harapan pengunjung merupakan tujuan penelitian ini. Pendekatan kualitas diterapkan untuk mengeksplorasi faktor-faktor mendasar persepsi kualitas pelayanan coffe shop di Kota Denpasar. Seratus pengunjung dilibatkan sebagai responden untuk mengukur kualitas pelayanan coffe shop. Hasil analisis Faktor menunjukkan bahwa Lingkungan pisik menyumbangkan variasi terhadap variasi kualitas yang terbesar, disusul oleh reliabilitas, kepastian, daya tanggap dan empati. Temuan penelitian ini merekomendasikan investor agar meletakkan perbaikan aspek pisik dalam prioritas utama, pemilihan lokasi yang strategis, kemudahan pembayaran, dan perhatian dan keramahan karyawan perlu ditingkatkan melalui pelatihan kompetensi untuk membangun sikap kerja yang sesuai.
\end{abstract}

Kata Kunci: kualitas, lingkungan pisik pelayanan, keandalan, daya tanggap, kepastian , empati.

\begin{abstract}
Increasing number of coffee shop s operating during the Pandemy in Denpasar City is the main reason of the present study. There is number coffee shop s available, while on the other hand Government regulation limited operating hours and capacity utilization which insist them to manage product and service delivery properly to their prospective custumer. Preliminary study uncovered that some areas dont meet customer expectancy such as waiter service behavior and appearance. The present study objective is exploring the fundamental factors that construct the quality of coffe shop in Denpasar area based on data accumulated from 100 coffe shop visitos. The result confirmed that dimensions of tangibility, reliability, responsiveness; assurance and empathy significantly explained variance of coffee shop quality. The Implication of the research finding is that investor have to put physical aspect improvement on the first priority to build positive consumer quality perception, chose strategic location, employ non cash payment method, and keep on improving cleanliness as well as train the employees to internalize hospitality attitude properly.
\end{abstract}

Keywords: physical evidence, reliability, responsiveness, assurance, and empathy. 


\section{PENDAHULUAN}

Coffee shop merupakan salah satu usaha jasa penyediaan makanan dan minuman, yang identik dengan meja dan kursi yang ditata dengan rapi, sofa yang nyaman, menjual aneka varian kopi, makanan kecil, adakalanya menawarkan juga makanan utama pada pengunjung (Poniman dan Sentosa, 2015). Awalnya coffee shop adalah restoran yang dibuka 24 jam di hotel. Saat ini marak usaha coffe shop di Kota Denpasar. Lokasi coffee shop tidak hanya dihotel tapi di pinggiran jalan dengan luas ruangan, tawaran produk makanan dan atmosfer yang bervariasi. Tahun 2020, jumlah coffee shop yang beroperasi di Kota Denpasar berjumlah 582 usah. (BPS Bali, 2020). Pertambahan jumlah Coffee shop disatu sisi belum dibarengi dengan kualitas pelayanan yang memenuhi harapan pengunjung. Studi awal mengungkapkan bahwa tujuan mengunjungi coffee shop antara lain untuk pertemuan, bekerja, memperoleh jaringan internet. Pengunjung coffee shop menyatakan bahwa tidak semua pengunjung diperhatikan kebutuhannya, pelaksana pelayanan memperlakukan pengunjung dengan cara yang berbeda, dan pilihan makanan dan minuman terbatas. Keluhan-keluhan yang disampaikan oleh pelanggan menunjukkan bahwa coffe shop belum mampu memenuhi harapan pengunjung. Kemampuan produk dan jasa memenuhi kebutuhan pelanggan disebut kualitas produk/jasa. Kualitas coffee shop dapat diukur melalui pendekatan dimensi: lingkungan pisik; Keandalan; Daya tanggap;Kepastian layanan; Empati. (Croin dan Taylor, 2012). Makanan, Minuman dan Harga juga berkaitan dengan kualitas coffee shop (Suhud et al.,2020). Kualitas pelayanan coffee shop berdampak pada loyalitas pelanggan di Korea Selatan (Shin et al.,2015).Pengukuran kualitas pelayanan dan produk yang ditawarkan kepada pelanggan penting bagi pengelola coffee shop di Kota Denpasar agar dapat meningkatkan kemampuan produk dan layanan. Sepanjang pengetahuan peneliti pengukuran kualitas produk dan pelayanan yang ditawarkan oleh coffee shop yang beroperasi di Kota Denpasar masih terbatas. Secara rinci penelitian ini bertujuan untuk: mengidentifikasi determinan kualitas pelayanan coffee shop di Kota Denpasar dan mengidentifikasi dimensi kualitas yang dominan memberikan sumbangan terhadap variasi kualitas pelayanan. Temuan penelitian memberikan rekomendasi bagi manajemen coffee shop dalam meningkatkan kualitas produk dan layanan guna membangun kepuasan pelanggan dan loyalitas pelanggan. 


\section{Kajian Pustaka.}

Pada bagian ini dijelaskan mengenai konseptualisasi kualitas pelayanan (Service Quality) coffee shop , Dimensi kualitas, Pengukuran Kualitas Dan Theory of Disconfirmation expectation yang menjelaskan hubungan kualitas pada perilaku pelanggan coffee shop .

Kualitas produk maupun jasa berdampak pada kinerja keuangan dan daya saing merek. Informasi terkait determinan kualitas merupakan masukan penting bagi service provider dalam pengembangan produk dan jasa kususnya differensiasi produk dan jasa berdasarkan elemen kualitas yang affordable sehingga berdampak terhadap kinerja operasional dan kinerja keuangan. Kualitas adalah penilaian pelanggan terkait apa yang seharusnya/diharapkan untuk diterima dengan apa yang sesungguhnya diterima oleh pelanggan. Teori Diskonfirmasi Ekspektasi menyatakan bahwa bila kualitas produk/jasa yang diterima oleh pelanggan lebih tinggi dibandingkan kualitas harapan, maka Pelanggan akan merasakan kepuasan. Sebaliknya bila kualitas produk/jasa yang diterima oleh pelanggan lebih rendah dibandingkan kualitas harapan maka pelanggan akan merasakan ketidakpuasan setelah mengkonsumsi produk/jasa tersebut. Kualitas produk atau jasa ditentukan oleh konsumen dan dipengaruhi oleh pengalaman individual konsumen yang membentuk harapan terkait produk atau jasa yang dikonsumsi. kualitas tidak hanya didasarkan pada produk akhir yang diserahkan, tapi dipengaruhi pula oleh proses penyerahan dan interaksi antara konsumen dan pelaksana pelayanan. (Globadian,Abby et all., 1994).

$$
\text { Parasuraman et al.,(1985) }
$$

mengungkapkan determinan kualitas meliputi :1)Keandalan (Reliability) adalah kemampuan menyerahkan jasa tepat waktu, akurat dan dapat diandalkan; 2) Daya tanggap(Responsiveness) kemampuan menangani keluhan pelanggan dan melakukan perbaikan/memberikan solusi terhadap masalah pelayanan;3) Keunikan pelayanan adalah kemampuan memberikan pelayanan sesuai kebutuhan pelanggan; 4)Kredibilitas adalah kepercayaan pelanggan pada perusahaan/toko yang direfleksikan pada reputasi dan citra toko yang posistif di mata pelanggan; 5)Kompetensi karyawan pelaksana pelayanan diwujudkan oleh kemampuan melaksanakan fungsi dan tugas pelayanan sesuai standar pelayanan secara effektif; 6) Aksesibilitas adalah kemudahan memperoleh pelayanan yang diwujudkan melalui lokasi toko yang strategik, mudah dijangkau , harga produk yang sesuai dengan kemampuan keuangan pasar sasaran, jadwal operasional yang sesuai dengan 
kebutuhan pelanggan.; 7) Kesantuan karyawan pelaksana pelayanan yang ditunjukkan oleh kesantunan, rasa hormat, keramahan dan pengertian karyawan pelaksana pada pelanggan; 8) Komunikasi adalah kemampuan menyampaikan informasi produk dan pelayanan secara efektif dan efisien, serta kemampuan memahami kebutuhan kusus pelanggan terkait produk, waktu pelayanan oleh provider; 9) Lingkungan pisik pelayanan adalah sana dan prasarana pelayanan yang digunakan dalam proses pelayanan meliputi penampilan karyawan, ruangan coffe shop, peralatan makan dan minum; 10) Pemahaman pada pelanggan (Understanding) adalah kemampuan memahami kebutuhan atau preferensi pelanggan reguler dan memenuhi preferensi secara efektif.

\section{Model Konseptuali Kualitas Pelayanan} Coffee shop .

Teori dissonansi kognitive menyatakan bahwa kesenjangan antara keyakinan dengan realitas terkait elemen/objek mengakibatkan ketidaknyamanan dan memicu respon konatif dalam bentuk sikap yang negatif terhadap objek kognitive. Teori ini menjadi dasar untuk memaknai keluhan pelanggan terkait sikap karyawan terhadap pelanggan coffe shop sebagai dissonansi negatif antara harapan perlakuan karyawan dengan realita perilaku karyawan terhadap pengunjung coffee shop yang dapat berdampak pada perilaku pasca konsumsi berupa ketidakpuasan individu pengunjung coffee shop. Dissonance negatif merupakan kesenjangan atau perbedaan dimana harapan kinerja produk dan pelayanan coffe shop lebih tinggi dari realita pelayanan yang dialami. Dissonansi merupakan diskonfirmasi harapan pelanggan dengan pengalaman nyata individu pelanggan dengan produk dan proses pelayanan coffee shop . Informasi terkait elemen yang belum sesuai dengan harapan pelanggan merupakan hal penting dalam peningkatan kualitas pelayanan dan keberlanjutan usaha coffee shop yang makin banyak jumlahnya di Bali dan Kota Denpasar kususnya. Greve (2014) menyatakan bahwa pelayanan yang cepat akan membuat usaha coffee shop mendapatkan imbalan dalam bentuk kunjungan ulang pengunjung untuk minum kopi atau santapan lain. Parasuraman et al., (1988) menyatakan bahwa kualitas pelayanan memiliki lima dimensi yang disajikan meliputi : Lingkungan pisik, keandalan, daya tanggap, kepastian layanan dan empati. Sejadi dan Rizzuto, (2013) menyatakan bahwa bukti pisik ditunjukkan oleh lingkungan dan fasilitas perusahaan, sikap pribadi dari pelayanan yang ramah, serta penampilan sarana dan prasarana fisik usaha coffee shop. 
Yusak et al., (2013) menyatakan bahwa bukti pisik termasuk kebersihan peralatan makan, ruangan coffee shop sementara Pakurar et al., (2019) menyatakan bahwa lingkungan pisik pelayanan membentuk citra coffee shop. Shin,C.S.,et al., (2015) membuktikan bahwa kualitas pelayanan coffee shop secara signifikan dipengaruhi oleh kualitas athmosfer toko dan kualitas pelayanan coffee shop.

$$
\text { Sejadi dan Rizzuto (2013) }
$$
mendefinisikan keandalan sebagai kemampuanunt untuk menyediakan produk/layanan sesuai apa yang telah disepakati/dijanjikan pada konsumen. Parasuraman et al., (1988) menyatakan bahwa keandalan merupakan kemampuan untuk memberikan pelayanan secara akurat, menyajikan pesanan tepat waktu atau pelayanan yang cepat (Nguye et al.,2018). Lee, J. H. (2013) mengungkapkan bahwa diantara faktor-faktor kualitas pelayanan coffee shop kualitas minuman kopi yang ditawarkan dan kepercayaan pada karyawan tidak signifikan dampaknya, sementara karakteristik menu dan lingkungan pelayanan signifikan pengaruhnya terhadap kualitas pelayanan.

Daya tanggap (Responsiveness) adalah tindakan memberikan bantuan kepada pengunjung mengatasi masalah (Sajadi dan Rizzoto, 2013). Kecepatan dalam menanggapi dan memperbaiki kesalahan merupakan wujud daya tanggap (Ababneh et al., 2018) seperti kecepatan karyawan dalam mengganti minuman yang tumpah, mengganti makanan yang salah disajikan.

Vanharanta, H., Kantola, J.,\& Seikola,S.(2015) melaporkan bahwa pengalaman individu pelanggan merupakan komponen yang penting dalam pembentukan kualitas pelayanan coffee shop. Pengalaman individu pelanggan dibentuk oleh proses interaksi pelanggan dan service provider yang dilaksanakan oleh karyawan garda depan para waiter maupun waitress.

Dimensi jaminan pelayanan (Assurance). menyatakan bahwa assurance adalah kemampuan pelayan coffee shop dalam memberikan kenyamanan dan keamanan kepada pengunjung (Sajadi dan Rizzuto, 2013), keramah-tamahan petugas pelayanan, pengetahuan pelayan terhadap menu-menu yang tersedia, dan kemampuan menjelaskan menu (Yusak, 2013).

\section{Dimensi Empati (Empahty)} menyatakan kemampuan memberikan perhatian secara kusus kepada pengunjung sesuai kebutuhan (Sejadi dan Rizzuto, 2013). Ladhari, R., Ladhari, I., \& Morales, M.(2011) menemukan bahwa dimensi empati sebagai sebagai kemampuan memberikan perhatian personal pada individu nasabah Bank merupakan faktor 
yang paling penting bagi nasabah Bank di Canada.

$$
\text { Model penelitian ini }
$$
mengidentifikasi struktur dimensi kualitas pelayanan coffee shop di Kota Denpasar. Parasuraman, Zeithmal dan Berry (1985), Shin et al.,(2015) dan Merimadi et al.,(2012) untuk lingkungan pelayanan coffee shop yang terdiri dari lima elemen/faktor kualitas yaitu lingkungan pisik, keandalan, daya tanggap, kepastian, dan empati dengan 20 indikator kualitas pada gambar 1 .

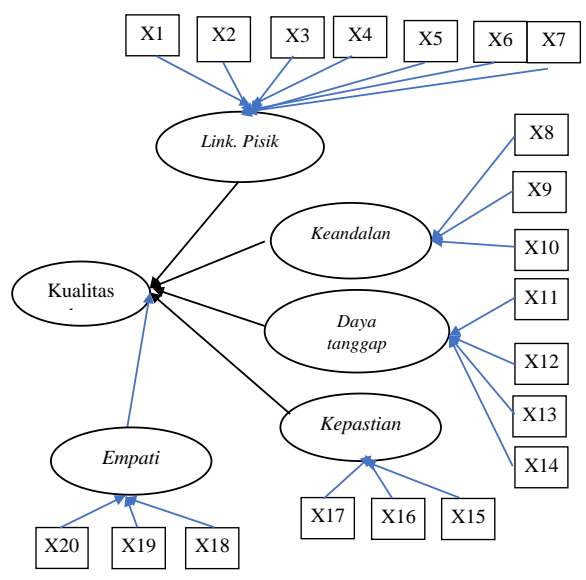

Gambar 1.

Model Konseptual penelitian (Cronin \&Taylor, 2012)

\section{Metode Penelitian.}

Analisis data dilakukan untuk menguji hipotesis penelitian bahwa variasi dimensi Tangibility (Lingkungan pisik pelayanan), Reliability (Keandalan pelayanan), Dependability (Daya Tanggap), Assurance (Kepastian pelayanan), Empathy (Pemahaman kebutuhan pelanggan) menyumbangkan variasi yang signifikan terhadap variasi kualitas layanan Coffee shop .

Penelitian ini mengambil lokasi pengumpulan di Kota Denpasar dengan responden penelitian adalah pengunjung usaha coffee shop periode bulan Oktober 2020 sampai Juli 202 dengan desain penelitian survei. Jumlah responden penelitian ditetapkan 100 orang pengunjung coffee shop berdasarkan pertimbangan jumlah butir indikator instrumen pengukuran data yang digunakan yaitu 20 dengan minimal 5 data pengamatan per indikator. Data penelitian meliputi data kualitatif seperti jenis kelamin pengunjung, lokasi tempat tinggal pengunjung, keluhan pelayanan dan persepsi terhadap lingkungan pisik, keandalan, daya tanggap, kepastian pelayanan dan empati petugas pelayanan yang dikumpulkan dari sumber primer yaitu pengunjung coffee shop yang terpilih sebagai responden. Data kuantitatif penelitian ini antara lain usia responden, frekuensi mengunjungi coffee shop dan nilai belanja setiap kunjungan dikumpulkan dari sumber data primer. Data kuantitatif yang dikumpulkan dari sumber sekunder adalah jumlah coffee shop yang beroperasi di Kota Denpasar tahun 2020.

Pengukuran data dilakukan dengan sekala likert yang terdiri dari 5 interval mewakili penilaian negatif hingga penilaian 
positif seperti Petugas Pelayanan (Sangat tidak memuaskan ----- Sangat memuaskan); Secara lengkap instrumen pengukuran data dimensi kualitas produk dan pelayanan coffe shop disajikan pada tabel 1.

Tabel 1.

Instrumen pengukuran Data

\begin{tabular}{|c|c|c|c|}
\hline Variable & Indikator & Kode & Sumber \\
\hline $\begin{array}{l}\text { Tagible (bukti } \\
\text { fisik) }\end{array}$ & $\begin{array}{ll}\text { 1. } & \text { Ruangan yang dimiliki bersih. } \\
\text { 2. } & \text { Lokasi coffee shop sangat strategis. } \\
\text { 3. } & \text { Peralatan kuliner bersih } \\
\text { 4. } & \text { Penampilan karyawan yang berpariasi. } \\
\text { 5. Menu yang bervariasi. } \\
\text { 6. Metode pembayaran yang sederhana. } \\
\text { 7. Penampilan minuman yang menarik. }\end{array}$ & $\begin{array}{l}\mathrm{X} 1 \\
\mathrm{X} 2 \\
\mathrm{X} 3 \\
\mathrm{X} 4 \\
\mathrm{X} 5 \\
\mathrm{X} 6 \\
\mathrm{X} 7\end{array}$ & \\
\hline $\begin{array}{l}\text { Reliability } \\
\text { (keandalan) }\end{array}$ & $\begin{array}{l}\text { 1. Karyawan di coffee shop sangat terampil. } \\
\text { 2. Karyawan coffee shop memiliki } \\
\text { pengetahuan yang baik. } \\
\text { 3. Karyawan coffee shop sangat ramah. } \\
\text { 4. Kecermatan dalam menulis pesanan } \\
\text { pengunjung. }\end{array}$ & $\begin{array}{l}\mathrm{X} 8 \\
\mathrm{X} 9 \\
\mathrm{X} 10 \\
\mathrm{X} 11\end{array}$ & Merimadi et al \\
\hline $\begin{array}{l}\text { Responsiveness } \\
\text { (daya tanggap) }\end{array}$ & $\begin{array}{l}\text { Karyawan selalu bersedia membantu } \\
\text { pelanggan ketika mengalami kesulitan. } \\
\text { 2. Karyawan memberikan pelayaan secara } \\
\text { cepat kepada pengunjung. } \\
\text { 3. Karyawan memberikan pelayanan secara } \\
\text { konsisten. }\end{array}$ & $\begin{array}{l}\mathrm{X} 12 \\
\mathrm{X} 13 \\
\mathrm{X} 14\end{array}$ & $\begin{array}{l}\text { (2012), Shin et al } \\
\text { (2015), Sejadi dan } \\
\text { Rizzoto, 2013, } \\
\text { Yusak, 2013. }\end{array}$ \\
\hline $\begin{array}{l}\text { Assurance } \\
\text { (jaminan) }\end{array}$ & $\begin{array}{ll}\text { 1. } & \text { Menjaga keamanan pengunjung } \\
\text { 2. Karyawan selalu bersikap jujur kepada } \\
\text { pengunjung. } \\
\text { 3. Pengunjung merasa nyaman dalam } \\
\text { bertransaksi. }\end{array}$ & $\begin{array}{l}\mathrm{X} 15 \\
\mathrm{X} 16 \\
\mathrm{X} 17\end{array}$ & \\
\hline $\begin{array}{l}\text { Emphaty } \\
\text { (empati) }\end{array}$ & $\begin{array}{l}\text { 1. Memberikan perhatian lebih kepada } \\
\text { pengunjung. } \\
\text { 2. Karyawan tidak membeda-bedakan } \\
\text { pelanggan. } \\
\text { 3. Karyawan mengerti kebutuhan } \\
\text { pengunjung. }\end{array}$ & $\begin{array}{r}\mathrm{X} 18 \\
\mathrm{X} 19 \\
\mathrm{X} 20\end{array}$ & \\
\hline
\end{tabular}

Pengujian hipotesis penelitian dilakukan dengan metode Analisis faktor, yang bertujuan mereduksi data sejumlah indikator variabel menjadi faktor yang mewakili dimensi kualitas pelayanan coffee shop. Kecukupan sampel data ditentukan oleh besaran Keiser Olkin dan Meyer (KMO) menetukan kecukupan sampel data yang dianalisis. Data dinilai cukup bila besaran KMO>0,50. Korelasi antar item dinilai berdasarkan nilai parameter Barlett's test of sphericty. Semakin kecil nilainya semakin tinggi korelasi antar butir indikator. Data diekstraksi dengan metode Principle Component Analysis untuk menguji signifikansi lima dimensi kualitas yang membentuk model konseptual kualitas.

Hasil ekstraksi mengidentifikasi Faktor-faktor inti yang dinilai signifikan dengan nilai Eigen minimal 1,0. Faktor inti merupakan representasi dimensi kualitas produk dan layanan coffee shop yang dibentuk oleh elemen butir indikator dimensi kualitas coffee shop yang memiliki nilai Loading terhadap Faktor minimal 0,40. Rotasi data berdasarkan metode Varimax menghasilkan elemen pembentuk faktor berdasarkan data empirik. Penamaan faktor hasil ekstraksi didasarkan pada definisi dimensi faktor atau indikator yang dominan dalam faktor tersebut.

\section{Hasil Analisis Data.}

Uji validitas dan reliabilitas yang dilakukan dengan metode Pearson dan metode scale menunjukkan bahwa data penelitian valid dan reliable. Tabel 2 menyajikan hasil uji validitas. Hasil Uji reliabilitas dengan metode scale menunjukkan nilai besaran Alpha Cronbah $=0,903$. Nilai ini lebih besar dari nilai kritis 0,60, menunjukkan bahwa data reliable.

Model analisis faktor dinilai layak berdasarkan nilai $\mathrm{KMO}=0,838$; Nilai Barlett's test of sphericty = Chi Square 1150,$123 ; \mathrm{p}<0,05$.

\section{Karakteristik Responden.}

Responden penelitian terdiri dari 100 orang, 43 orang berjenis kelamin 
perempuan dan 57 orang berjenis kelamin laki - laki. Responden sebagian besar berusia 20-29 tahun sebesar 82\%; persentase responden yang berusia 30-39 tahun sebesar 5\% dan yang berusia dibawah 20 tahun sebesar $13 \%$.

\section{Tabel 2}

Hasil Uji Validitas Butir Indikator.

\begin{tabular}{lcc}
\multicolumn{1}{c}{ Indikator } & Nilai korelasi & Keterangan \\
\hline Kebersihan ruangan $\mathrm{X}_{1}$ & 0,791 & Valid \\
\hline Lokasi coffee shop $\mathrm{X}_{2}$ & 0,791 & Valid \\
\hline Kebersihan peralatan $\mathrm{X}_{3}$ & 0,776 & Valid \\
\hline penampilan karyawan bervariasi $\mathrm{X}_{4}$ & 0,798 & Valid \\
\hline Daftar menu yang bervariasi $\mathrm{X}_{5}$ & 0,840 & Valid \\
\hline Metode pembayaran $\mathrm{X}_{6}$ & 0,640 & Valid \\
\hline Daya tarik sajian minuman $\mathrm{X}_{7}$ & 0,496 & Valid \\
\hline Keterampilan karyawan $\mathrm{X}_{8}$ & 0,879 & Valid \\
\hline Pengetahuan karyawan $\mathrm{X}_{9}$ & 0,684 & Valid \\
\hline Keramahan karyawan $\mathrm{X}_{10}$ & 0,870 & Valid \\
\hline Kecermatan menulis pesanan pengunjung $\mathrm{X}_{11}$ & 0,630 & Valid \\
\hline Bersedia membantu pengunjung $\mathrm{X}_{12}$ & 0,458 & Valid \\
\hline Kecepatan pelayanan yang diberikan $\mathrm{X}_{13}$ & 0,573 & Valid \\
\hline Konsistensi memberikan pelayanan $\mathrm{X}_{14}$ & 0,619 & Valid \\
\hline Keamanan lingkunga pelayanan $\mathrm{X}_{15}$ & 0,661 & Valid \\
\hline Kejujuran karyawan $\mathrm{X}_{16}$ & 0,567 & Valid \\
\hline Kenyamanan bertaransaksi $\mathrm{X}_{17}$ & 0,763 & Valid \\
\hline Perhatian karyawan $\mathrm{X}_{18}$ & 0,824 & Valid \\
\hline Keadilan karyawan $\mathrm{X}_{19}$ & 0,505 & Valid \\
\hline Kepekaan karyawan $\mathrm{X}_{20}$ & 0,675 & Valid \\
\hline & &
\end{tabular}

Sumber : data diolah.

Responden kebanyakan telah memiliki pengalaman mengunjungi coffee shop minimal 5 kali dengan persentase $61 \%$; Empat kali persentase 10\%, tiga kali persentase $14 \%$; dan yang telah mengujungi coffee shop dua kali 2 kali persentasenya 15\%. Lokasi tempat tinggal resonden sebagian besar di wilayah Denpasar dengan persentase $61 \%$, sementara yang lainnya tinggal di wilayah Gianyar (5\%); Tabanan $(6 \%)$; Badung (11\%), dan wilayah lain di Bali sejumlah $17 \%$.

Persepsi pengunjung untuk dimensi pisik kualitas produk dan layanan coffee shop disajikan pada tabel 3.
Tabel 3

Persepsi Lingkungan Pisik Pelayanan

\begin{tabular}{cclcc}
\hline \multirow{2}{*}{ Variabel } & Kode & \multicolumn{1}{c}{ Indikator } & $\begin{array}{c}\text { Rata- } \\
\text { rata }\end{array}$ & Interpretasi \\
\hline & $\mathrm{X} 1$ & Ruangan coffe shop bersih & 4,19 & Memuaskan \\
\cline { 2 - 5 } & $\mathrm{X} 2$ & $\begin{array}{l}\text { Lokasi coffee shop } \\
\text { strategis. }\end{array}$ & 3,98 & Memuaskan \\
\cline { 2 - 5 } $\begin{array}{c}\text { Tangibles } \\
\text { (bukti fisik) }\end{array}$ & $\mathrm{X}$ Peralatan kuliner bersih. & 4,23 & $\begin{array}{c}\text { Sangat } \\
\text { Memuaskan }\end{array}$ \\
\cline { 2 - 5 } & $\mathrm{X} 4$ & $\begin{array}{l}\text { Penampilan karyawan yang } \\
\text { rapi }\end{array}$ & 4,41 & $\begin{array}{c}\text { Sangat } \\
\text { Memuaskan }\end{array}$ \\
\cline { 2 - 5 } & $\mathrm{X}$ Variasi menu coffee shop & 4,39 & $\begin{array}{c}\text { Sangat } \\
\text { Memuaskan }\end{array}$ \\
\cline { 2 - 5 } & $\mathrm{X} 6$ & $\begin{array}{l}\text { Metode pembayaran } \\
\text { mudah. }\end{array}$ & 4,23 & $\begin{array}{c}\text { Sangat } \\
\text { Memuaskan }\end{array}$ \\
\cline { 2 - 5 } & $\mathrm{X} 7$ & $\begin{array}{l}\text { Penampilan minuman yang } \\
\text { menarik. }\end{array}$ & 4,26 & $\begin{array}{c}\text { Memuaskan } \\
\text { Rata }- \text { Rata }\end{array}$ \\
\hline & $\mathbf{4 , 2 4}$ & $\begin{array}{c}\text { Sangat } \\
\text { Memuaskan }\end{array}$ \\
\hline
\end{tabular}

Sumber : data diolah.

Meskipun skor rata-rata menunjukkan bahwa persepsi dimensi lingkungan pisik sangat memuaskan, namun data menunjukkan bahwa lokasi coffee shop $(3,29)$ dan metode pembayaran $(4,23)$ merupakan aspek yang memiliki skor lebih rendah dari skor rata-rata faktor lingkung coffee shop $(4,24)$.

Persepsi pengunjung coffee shop terhadap dimensi keandalan disajikan pada tabel 4 .

\section{Tabel 4}

Persepsi Keandalan Pelayanan

\begin{tabular}{cllcc}
\hline Variabel & Kode & \multicolumn{1}{c}{ Indikator } & $\begin{array}{c}\text { Rata- } \\
\text { rata }\end{array}$ & interpretasi \\
\hline & $\mathrm{X} 8$ & $\begin{array}{l}\text { Karyawan di coffee shop } \\
\text { sangat terampil. }\end{array}$ & 4,02 & Memuaskan \\
\cline { 2 - 5 } X9 & $\begin{array}{l}\text { Karyawan di coffee shop } \\
\text { memiliki pengetahuan }\end{array}$ & 4,34 & $\begin{array}{c}\text { Sangat } \\
\text { Memuaskan }\end{array}$ \\
\cline { 2 - 5 }$($ Keliability & yang baik. & 4,09 & Memuaskan \\
\cline { 2 - 5 } & $\mathrm{X} 10$ & $\begin{array}{l}\text { Karyawan coffee shop } \\
\text { sangat ramah. }\end{array}$ & 4,36 & $\begin{array}{c}\text { Sangat } \\
\text { Xemuaskan }\end{array}$ \\
\cline { 2 - 5 } & $\begin{array}{l}\text { Kecermatan karyawan } \\
\text { dalam menulis pesanan } \\
\text { pengunjung. }\end{array}$ & $\mathbf{4 , 2 0}$ & Memuaskan \\
\hline Rata - Rata & & \\
\hline
\end{tabular}

Sumber: data diolah.

Data rata-rata skor keandalan (Reliabilitas) yang disajikan dalam Tabel 4, 
menunjukkan bahwa persepsi keandalan pelayanan memuaskan (4,20).Indikator kecermatan menulis pesanan merupakan indikator yang dinilai paling tinggi oleh pengunjung $(4,36)$, sementara indikator ketrampilan karyawan memiliki nilai ratarata skor paling rendah $(4,02)$ dan indikator keramahan karyawan $(4,09)$.

Persepsi pengunjung coffee shop terhadap dimensi daya tanggap (Responsiveness) disajikan pada Tabel 5.

Tabel 5

Persepsi Daya Tanggap Pelayanan

\begin{tabular}{cllcc}
\hline Variabel & Kode & \multicolumn{1}{c}{ Indikator } & $\begin{array}{c}\text { Rata- } \\
\text { rata }\end{array}$ & Interpretasi \\
\hline & $\mathrm{X} 12$ & $\begin{array}{l}\text { Karyawan membatu } \\
\text { mengatasi masalah } \\
\text { pengunjung }\end{array}$ & 4,15 & Memuaskan \\
\cline { 2 - 5 } $\begin{array}{l}\text { Responsiveness } \\
\text { (daya tanggap) }\end{array}$ & $\begin{array}{l}\text { Karyawan memberikan } \\
\text { pelayanan tepat kepada } \\
\text { pengunjung }\end{array}$ & 4,08 & Memuaskan \\
\cline { 2 - 5 } & $\mathrm{X} 14$ & $\begin{array}{l}\text { Karyawan memberikan } \\
\text { pelayanan secara } \\
\text { konsisten. }\end{array}$ & 4,67 & Memuaskan \\
\hline & Rata - Rata & $\mathbf{4 , 3 0}$ & $\begin{array}{c}\text { Sangat } \\
\text { Memuaskan }\end{array}$ \\
\hline
\end{tabular}

Sumber: data diolah

Skor rata-rata persepsi daya tanggap menunjukkan daya tanggap (responsiveness) dikategorikan sangat memuaskan (4,30). Indikator Konsistensi pelayanan merupakan indikator yang memiliki skor rata-rata tertinggi $(4,67)$. Indikator yang memiliki skor rata-rata lebih rendah dari skor rata-rata faktor adalah indikator ketepatan pelayanan (4.08) dan indikator mengatasi masalah pengunjung $(4,15)$.

\section{Persepsi kepastian pelayanan} (assurance) terdiri dari tiga indikator. Data skor rata-rata persepsi kepastian
pelayanan(Assurance) disajikan pada Tabel 6. Data skor rata-rata kepastian layanan adalah 4,37, dikategorikan sangat memuaskan.

\section{Tabel 6}

Persepsi Kepastian Pelayanan

\begin{tabular}{cclcl}
\hline \multirow{2}{*}{ Variabel } & Kode & \multicolumn{1}{c}{ Indikator } & Rata-rata & Interpretasi \\
\hline & $\mathrm{X} 15$ & $\begin{array}{l}\text { Menjaga keamanan } \\
\text { bertransaksi }\end{array}$ & 3,97 & Memuaskan \\
\cline { 2 - 5 } $\begin{array}{c}\text { Assurance } \\
\text { (jaminan) }\end{array}$ & $\mathrm{X} 16$ & $\begin{array}{l}\text { Karyawan bersikap jujur } \\
\text { kepada pengunjung. }\end{array}$ & 4,54 & $\begin{array}{l}\text { Sangat } \\
\text { Memuaskan }\end{array}$ \\
\cline { 2 - 5 } & $\mathrm{X} 17$ & $\begin{array}{l}\text { Pengunjung merasa aman } \\
\text { dalam bertransaksi. }\end{array}$ & 4,62 & $\begin{array}{l}\text { Sangat } \\
\text { Memuaskan }\end{array}$ \\
\hline \multirow{2}{*}{ Rata - Rata } & $\mathbf{4 , 3 7}$ & $\begin{array}{c}\text { Sangat } \\
\text { Memuaskan }\end{array}$ \\
\hline
\end{tabular}

Sumber: data diolah

Indikator keamanan transaksi merupakan indikator faktor kepastian layanan yang memiliki skor lebih tertinggi $(4,62)$ dibandingkan indikator kejujuran karyawan $(4,54)$. Indikator keamanan pengunjung memiliki skor rata-rata terendah bahkan lebih rendah dari skor rata-rata total faktor kepastian layanan $(4,37)$.

Persepsi empati pelayanan diukur dengan tiga indikator. Data skor rata-rata masing-masing indikator pengukuran faktor empati disajikan pada Tabel 7.

Tabel 7

Persepsi Empati Pelayanan

\begin{tabular}{cclcc}
\hline Variabel & Kode & \multicolumn{1}{c}{ Indikator } & $\begin{array}{c}\text { Rata- } \\
\text { rata }\end{array}$ & Kategori \\
\hline & X18 & $\begin{array}{l}\text { Memberikan perhatian } \\
\text { kepada pengunjung. }\end{array}$ & 3,51 & Memuaskan \\
\cline { 2 - 5 } $\begin{array}{c}\text { Empathy } \\
\text { (empati) }\end{array}$ & X19 & $\begin{array}{l}\text { Karyawan tidak membeda- } \\
\text { bedakan pelanggan. }\end{array}$ & 4,1 & Memuaskan \\
\cline { 2 - 5 } & X20 & $\begin{array}{l}\text { Karyawan mengerti } \\
\text { kebutuhan pengunjung. }\end{array}$ & 3,73 & Memuaskan \\
\hline & Rata - Rata & $\mathbf{3 , 7 8}$ & Memuaskan \\
\hline
\end{tabular}

Sumber: data diolah.

Skor rata-rata total persepsi empati pelayanan sebesar 3,78 dikategorikan 
memuaskan. Indikator empati yang memiliki skor rata-rata tertinggi adalah perilaku karyawan yang tidak diskriminatif dalam melayani pelanggan coffee shop $(4,1)$. Indikator kemampuan memberikan perhatian pada pengunjung memiliki skor rata-rata terendah $(3,51)$. Pemahaman terhadap kebutuhan pelanggan memiliki skor lebih rendah dari skor rata-rata total faktor empati $(3,73)$.

Tabel 8 menyajikan lima faktor hasil ekstraksi Faktor yang memiliki nilai Eigen lebih besar dari 1,0. Total variasi yang disumbangkan oleh kelima faktor menjelaskan variasi kualitas pelayanan sebesar 68.761 persen.

Tabel 8

Total Varian Qualitas Yang Dijelaskan

\begin{tabular}{lrrr}
\hline \multirow{2}{*}{ Component } & \multicolumn{4}{c}{ Rotation Sums of Squared Loadings } \\
\cline { 2 - 4 } & Total & \% of Variance & Cumulative \% \\
\hline 1 & 3,960 & 19,800 & 19,800 \\
\hline 2 & 3,402 & 17,010 & 36,810 \\
\hline 3 & 2,532 & 12,661 & 49,471 \\
\hline 4 & 2,228 & 11,140 & 60,611 \\
\hline 5 & 1,630 & 8,150 & 68,761 \\
\hline
\end{tabular}

Sumber: data diolah.

Nilai kontribusi masing - masing faktor/dimensi kualitas pelayanan coffee shop adalah;

1) Faktor 1 disebut Faktor lingkungan fisik (Tangibles) memiliki nilai eigen sebesar 3,960 dengan persentase sumbangan variasi menjelaskan variasi kualitas sebesar $19,8 \%$

2) Faktor 2 disebut Faktor keandalan (reliability) memiliki nilai eigen sebesar 3,402 dengan dengan persentase sumbangan variasi menjelaskan variasi kualitas sebesar 17,010,

3) Faktor 3 empati (emphaty) memiliki nilai eigen sebesar 2,532 dengan dengan persentase sumbangan variasi menjelaskan variasi kualitas sebesar 12,661 .

4) Faktor 4 disebut faktor kepastian layanan (Assurance) memiliki nilai eigen sebesar 2,228 dengan persentase sumbangan variasi menjelaskan variasi kualitas sebesar 11,140.

5) Faktor 5 disebut faktor daya tanggap (responsiveness) memiliki nilai eigen sebesar 1,630 dengan persentase sumbangan variasi menjelaskan variasi kualitas varian sebesar 8,150 .

Hasil rotated component matrik disajikan pada Tabel 9 lebih detil menunjukkan indikator kualitas layanan coffe shop yang signifikan berkorelasi dengan masing-masing faktor inti, ditunjukkan oleh besaran nilai Loading indikator butir indikator terhadap Faktor yang terkait.

\section{Interpretasi Hasil Analisis.}

Hasil analisis faktor secara umum menjelaskan bahwa dari 20 indikator membentuk lima faktor kualitas pelayanan coffee shop dengan kemampuan menjelaskan variasi kualitas pelayanan coffee shop sebesar 68,761. 
Faktor - faktor tersebut yaitu Faktor Lingkungan pisik menyumbangkan variasi kualitas pelayanan coffee shop sebesar 19,8 persen dengan nilai Eigen 3,960. Data skor rata-rata faktor kepastian layanan adalah 4,37, dikategorikan sangat memuaskan.

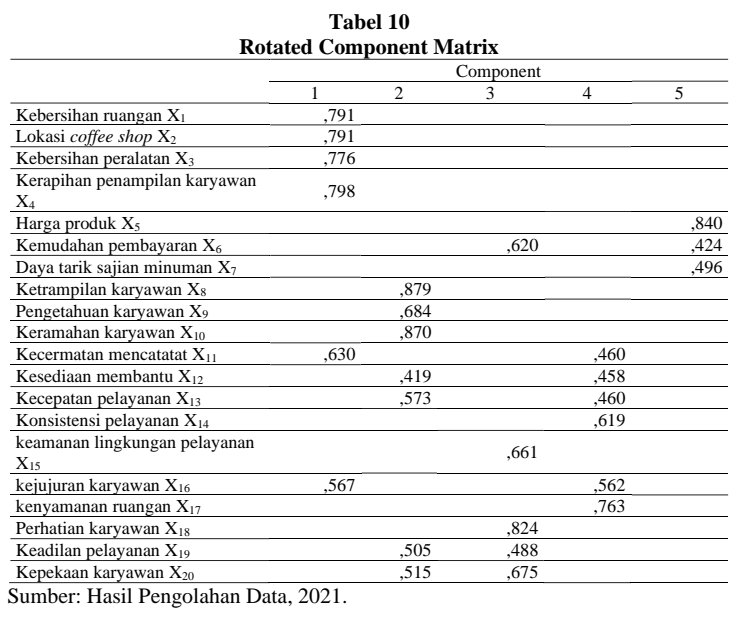

Elemen faktor lingkungan pisik yang memiliki korelasi paling kuat hingga paling lemah dengan faktor lingkungan pisik ditunjukkan oleh nilai Loading berturutturut adalah : Kebersihan ruangan (0,791); Lokasi coffee shop (0,791); Penampilan karyawan yang bersih dan rapi $(0,798)$; Kebersihan peralatan makan dan minum $(0,776)$; Kecermatan memproses pesanan pelanggan (0,630); Kejujuran karyawan $(0,567)$. Elemen lingkungan pisik yang memiliki dampak paling kuat terhadap kualitas adalah Kebersihan ruangan coffee shop.

Faktor keandalan karyawan memiliki nilai Eigen sebesar 3,402 dan menyumbangkan variasi terhadap kualitas pelayanan coffee shop sebesar 17 persen.
Elemen faktor keandalan karyawan yang memiliki korelasi paling kuat hingga paling lemah dengan faktor keandalan ditunjukkan oleh nilai Loading berturutturut adalah : Ketrampilan karyawan $(0,879)$; Keramahan karyawan $(0,870)$; Pengetahuan karyawan $(0,684)$; Kecepatan dan ketepatan pelayanan (0,576); Elemen kesamaan perlakuan / karyawan tidak membeda-bedakan pengunjung $(0,505)$. Elemen faktor keandalan yang paling kuat dampaknya terhadap kualitas adalah ketrampilan karyawan $(0,879)$.

Faktor empati karyawan memiliki nilai Eigen sebesar 2,532 dan menyumbangkan variasi terhadap kualitas pelayanan coffee shop sebesar 12,6 persen. Elemen faktor empati karyawan yang memiliki korelasi paling kuat hingga paling lemah dengan faktor empati ditunjukkan oleh nilai Loading berturut-turut adalah : Perhatian karyawan $(0,824)$; Pemahaman pada Kebutuhan pelanggan (0,661); Keamanan (0,661);Metode pembayaran pembayaran (0,620). Elemen faktor keandalan yang paling kuat dampaknya terhadap kualitas adalah perhatian karyawan $(0,824)$.

Faktor jaminan pelayanan memiliki nilai Eigen sebesar 2,228 dan menyumbangkan variasi terhadap kualitas pelayanan coffee shop sebesar 11,1 persen. Elemen faktor jaminan kualitas 
pelayanan yang memiliki korelasi paling kuat hingga paling lemah dengan faktor empati ditunjukkan oleh nilai Loading berturut-turut adalah : Keamanan bertransaksi $(0,736)$; Konsistensi pelayanan pelanggan (0,619); Membantu kesulitan pengunjung $(0,458)$; Metode pembayaran pembayaran (0,620).Elemen faktor kepastian pelayanan yang paling kuat dampaknya terhadap kualitas adalah perhatian karyawan $(0,736)$.

Faktor Menu dan tampilan minuman memiliki nilai Eigen sebesar 1,630 dan menyumbangkan variasi terhadap kualitas pelayanan coffee shop sebesar 8,1 persen. Elemen faktor Variasi Menu dan tampilan minuman yang memiliki korelasi paling kuat hingga paling lemah dengan faktor Menu dan tampilan minuman ditunjukkan oleh nilai Loading berturut-turut adalah : Variasi Menu (0,736); Penampilan minuman (0,496).Elemen faktor Menu dan tampilan minuman yang paling kuat dampaknya terhadap kualitas adalah Variasi menu $(0,840)$.

\section{Pembahasan Dan Implikasi Temuan.}

Berdasarkan nilai total akumulatif parameter Total Explained Variance sebesar 68,76 persen, menunjukkan bahwa kelima faktor yang dibentuk oleh 20 elemen aspek pelayanan coffee shop mampu menjelaskan 68,76 persen variasi persepsi kualitas pelayanan coffee shop yang beroperasi di Kota Denpasar. Nilai Eigen dan nilai total explained variance masingmasing faktor menceriminkan pengaruh relatif terhadap variasi persepsi kualitas pelayanan. Faktor lingkungan pisik pelayanan, memberikan sumbangan variasi terhadap persepsi kualitas coffee shop yang paling kuat yaitu sebesar 19,8 persen dengan elemen yang paling kuat korelasinya terhadap faktor lingkungan pisik adalah kerapihan penampilan karyawan (0,798). Elemen lingkungan pisik yang paling lemah korelasinya adalah kejujuran karyawan (0,567). Hasil analisis data deskriptif menunjukkan bahwa elemen faktor lingkungan pisik yang paling rendah skornya berdasarkan persepsi pelanggan adalah lokasi coffee shop $(3,98)$, sementara skor tertinggi adalah elemen Kerapihan penampilan karyawan $(4,41)$. Informasi ini merekomendasikan bahwa manajemen coffee shop dengan memilih lokasi coffee shop yang mudah dijangkau oleh calon pelanggan.

Nilai Eigen dan nilai loading faktor keandalan pelayanan memberikan sumbangan variasi terhadap persepsi kualitas coffee shop sebesar 17 persen dengan elemen faktor yang paling kuat korelasinya terhadap faktor keandalan pelayanan adalah ketrampilan karyawan $(0,879)$. Elemen keandalan pelayanan yang paling lemah korelasinya dengan faktor 
keandalan pelayanan adalah perlakuan karyawan $(0,505)$. Elemen faktor keandalan pelayanan yang paling rendah skornya berdasarkan persepsi pelanggan adalah ketrampilan karyawan coffee shop $(4,02)$ dan keramahan karyawan coffee shop $(4,02)$, sementara skor tertinggi adalah elemen kecermatan memproses pesanan pelanggan $(4,36)$.

Temuan ini menunjukkan bahwa manajemen perlu memelihara dan meningkatkan ketrampilan key personal coffee shop untuk menciptakan konsistensi dan kecepatan layanan melalui pelatihan kompetensi fungsional sesuai jabatan kerja.

Nilai Eigen faktor empati dan nilai loading masing-masing elemen faktor empati menunjukkan bahwa elemen perhatian karyawan memiliki korelasi yang paling kuat $(0,824)$ kemudian pemahaman terhadap kebutuhan pengunjung $(0,675)$, dan keamanan pengunjung $(0,661)$ serta dan metode pembayaran $(0,620)$. Untuk meningkatkan kualitas layanan manajemen dapat perlu memberikan pelatihan pengembangan karyawan untuk meningkatkan kepekaan dan pemahaman terhadap kebutuhan pengunjungan coffee shop Nilai Eigen faktor kepastian layanan dan nilai loading masing-masing elemen faktor kepastian pelayanan menunjukkan elemen faktor kepastian kualitas yang paling kuat adalah keamanan bertransaksi (0,736). Elemen jaminan kualitas pelayanan yang paling lemah korelasinya kesediaan membantu pelanggan $(0,458)$. menunjukkan bahwa prioritas keempat dalam meningkatkan persepsi kualitas pelayanan adalah meningkatkan keamanan bertransaksi di coffee shop.

Nilai Eigen dan nilai loading elemen faktor Menu dan tampilan makanan menunjukkan bahwa variasi menu dan tampilan makanan memberikan sumbangan variasi terhadap persepsi kualitas coffee shop. Elemen yang paling kuat korelasinya terhadap faktor menu dan tampilan makanan adalah Variasi Menu (0,840). Informasi merekomendasikan agar manajemen coffee shop mengembangkan menu baru, menyajikan makanan dan minuman yang bervariasi serta menyajikan dengan cara yang menarik. Temuan penelitian ini menguatkan temuan Shin et al., 2015 yang menyatakan bahwa lingkungan pisik coffee shop, keramahan karyawan dan kemampuan memahami kebutuhan kusus pelanggan serta perhatian pada pelanggan berdampak pada persepsi kualitas layanan coffee shop. Selaras dengan temuan Yusak et al., (2013) bahwa lingkungan pisik coffee shop meliputi kebersihan peralatan makan, kebersihan ruangan coffee shop. Pakurar et al., (2019) menyatakan pula bahwa pelanggan menilai 
kualitas pelayanan berdasarkan indikator lingkungan pisik coffee shop.

Hasil rotasi komponen matrik mengungkapkan bahwa kemudahan pembayaran berkorelasi dengan faktor empati dan faktor harga. Penelitian selanjutnya perlu memasukkan variabel harga dengan nilai yang bervariasi dan variasi metode pembayaran untuk menguji hubungannya dengan empati pelayanan. Apakah kemudahan pembayaran dan harga yang terjangkau mencerminkan peningkatan daya jangkau pelayanan bagi pelanggan. Indikator kesediaan membantu mengatasi masalah pelanggan dan kecepatan pelayanan berkorelasi dengan faktor empati dan faktor kepastian pelayanan. Temuan ini menunjukkan bahwa kesediaan membantu mengatasi masalah pelanggan dan kecepatan pelayanan memberikan sumbangan varian terhadap faktor empati karyawan dan kepastian pelayanan. Penelitian selanjutnya perlu menguji lebih lanjut bagaimana kecepatan pelayanan berkorelasi dengan empati dan kepastian pelayanan.

\section{Keterbatasan Penelitian}

Meskipun temuan penelitian memberikan informasi terkait kualitas pelayanan coffee shop di wilayah kota Denpasar dan faktorfaktor pelayanan yang memberikan sumbangan signifikan terhadap kualitas pelayanan serta indikator kualitas pelayanan coffee shop, namun temuan ini memiliki keterbatasan karena hanya melibatkan pengunjung lokal sebagai responden penelitian. Tingkat keterlibatan dibuktikan mempengaruhi persepsi kualitas pelayanan coffee shop . Penelitian berikutnya disarankan untuk memasukkan variabel keterlibatan pelanggan coffee shop dalam model konseptual penelitian, untuk menguji apakah terdapat perbedaan struktur faktor pembentuk kualitas pelayanan coffee shop pada kelompok pelanggan dengan keterlibatan tinggi dibandingkan kelompok pelanggan dengan keterlibatan tinggi. Informasi terkait perilaku pelanggan coffee shop yang memiliki keterlibatan tinggi merupakan masukan berharga dalam merumuskan strategy pemasaran coffee shop karena kelompok pelanggan ini melakukan volumen pembelian dan nilai pembelian yang lebih tinggi dibandingkan kelompok pelanggan dengan keterlibatan rendah sehingga mewujudkan kualitas pelayanan berdasarkan perspektif kelompok pelanggan ini memberikan peluang perolehan manfaat ekonomi yang lebih tinggi dan keberlanjutan usaha yang lebih tinggi. Pengumpulan data penelitian ini dilakukan pada saat pandemic Covid-19, sehingga terdapat keterbatasan pengunjung yang menjadi responden dalam menjawab pertanyaan dan harus tetap menaati protokol kesehatan yang ada, sedangkan 
dengan menggunakan google from pengunjung akan sulit untuk diwawancarai.

\section{Simpulan Dan Saran.}

hasil analisis data mengungkapkan bahwa:

1. Faktor lingkungan pisik, keandalan pelayanan, empati, kepastian pelayanan dan Menu dan tampilan makanan memberikan sumbangan varian kualitas pelayanan coffee shop sebesar 68, 761\%.

2. Diantara kelima faktor yang menyumbangkan variasi kualitas pelayanan coffee shop, Faktor lingkungan pisik dibuktikan memberikan sumbangan varian yang paling kuat terhadap kualitas pelayanan dengan nilai eigen 3,960 dan nilai variance explained $19,80 \%$.

\section{Saran.}

Hasil analisis data deskriptif menunjukkan bahwa elemen faktor lingkungan pisik yang paling rendah skornya berdasarkan persepsi pelanggan adalah lokasi coffee shop, pemilihan lokasi merupakan keputusan yang mempengaruhi kualitas coffee shop oleh pengunjung, maka investor disarankan memilih lokasi usaha coffee shop di lingkungan yang mudah dijangkau. Ketrampilan karyawan, keramahan karyawan merupakan komponen keandalan pelayanan yang mempengaruhi persepsi kualitas pelayanan coffee shop. Manajemen disarankan melaksanakan program pelatihan secara berkelanjutan untuk meningkatkan ketrampilan dan membangun sikap kerja karyawan berorientasi pada pelanggan. Manajemen coffee shop perlu menerapkan sistem keamanan yang andal untuk mengantisipasi terjadinya peristiwa yang berdampak pada keamanan pisik pengunjung dan hak milik pengunjung coffee shop.

\section{DAFTAR PUSTAKA}

Anonim. 2016. Peraturan Menteri Pariwisata Nomor 18 Tahun 2016 Tentang Pendaftaran Usaha Pariwisata 2020. Badan Pusat Statistik Bali

Astina, I N. G. 2017. Pengaruh Kualitas Layanan Berbasis Kearifan Lokal Bali Terhadap Kepuasan dan Niat Perilaku Loyal Wisatawan Mancanegara pada Hotel Non Bintang di Bali. Disertasi. Program Studi Doktor Pariwisata Fakultas Pariwisata Universitas Udayana

Al-Ababneh, M.M., Masadeh, M.A., AlShakhsheer, F.J. and Habiballah, M.A. (2018). The impact of internal service quality on job satisfaction in the hotel industry. Research in Hospitality Management. Vol. 8 No. 1, 55-62

Ayelign, A., dan Sabally, K. 2013. Determination of Chlorogenic Acids (CGA) in Coffee Beans Using HPLC. American Journal of Research Communication

Chuah, H. W., Marimuthu, M., dan Ramayah, T. 2014. The effect of Perceived Value o the Loyalty of Generation Y. Social and Behavioral Sciences. 130:532-541 
Cronin, J. J., dan Taylor, S. A. 1992. Measuring Service Quality: A Reexamination and Extention. Journal of Marketing. 56(3):55-68

Demirgunes, B. K. 2015. Relative Importance of Perceived Value, Satisfaction and Perceived Risk on willingness to Pay More. Internasional Review of Management and Marketing. 5(4):211-220

Ghozali, Imam. 2012. Aplikasi Analisis Multivariat dengan Program IMB SPSS. Yogyakarta: Universitas Diponegoro.

Vanharanta, H., Kantola, J., \& Seikola, S. (2015). Customers' conscious experience in a coffee shop Procedia Manufacturing, 3, 618-625.

Heary, F. A. 2014. Studying the Effect of Food Quality and Dimension (Physical Enviroment, Food and Service) on Mental Image of the Restaurant and Customer Satisfaction and Internasional Based on Kisang Model. Internasional Journal of Academic Research in Business and Social Sciences. 4(7):415-430

J. Joseph Cronin, Jr. and Steven A, Taylor. 2012. Measuring Service Quality: A Reexamination and Extention Jurnal Marketing. 55.56-68

Ishak, R. P., dan Maharani, N. 2020. Pengaruh Kualitas Pelayanan terhadap Kepuasan Konsumen di Coffee Toffeen Post Shop Bogor. Jurnal Perjalanan Wisata Destinasi dan Hospitality. 3(1):17-34

Kotler, P., dan Armstrong, G. 2012. Prinsipprinsip Pemasaran. Edisi 13. Jilid 1. Jakarta: Erlangga

Kim, B., Yoon, J., dan Moon, S. 2013. Effects of Service Quality on Customer Satisfaction, Brand Image, and Customer Loyalty of Female University Students in a Coffee shop . The Journal of the Korea Contents Association. 13(12):428438

Kim, H. A. (2008). Importanceperformance analysis of service quality of in campus specialty coffee shop . Journal of the Korean Society of Food Science and Nutrition, 37(8), 1069-1078.

Kim, H., \& Kim, B. G. (2015). Comparison with service quality models in coffee shop . Culinary science and hospitality research, 21(5), 50-58.

Lankton, N. K., \& McKnight, H. D. (2012). Examining two expectation disconfirmation theory models: assimilation and asymmetry effects. Journal of the Association for Information Systems, 13(2), 1.

Lazarevic, V. 2012. Encouraging Brand Loyalty in Fickle Generation Y Consumers. Young Consumer. 13(1):45-61.

Ladhari, R., Ladhari, I., \& Morales, M. (2011). Bank service quality: comparing Canadian and Tunisian customer perceptions. International Journal of Bank Marketing.

Lee, J. H. (2013). A study on the effect of coffee shop service quality on perceived value and behavioral intention-Focusing on Busan-area college students. Culinary science and hospitality research, 19(3), 218-233.

Mohajerani, P., dan Miremadi, A. 2012. Customer Satisfaction Modeling in Hotel Industry: a Case Study of Kish Island in Iran. International Journal of Marketing Studies. 4(3):134-152

Moleong, L. 2014. Metodologi Penelitian Kualitatif. Edisi Revisi. Bandung: PT Remaja Rosdakarya 
Mowen, J. dan Minor, M. 2002. Perilaku Konsumen. Jilid 1 Edisi Kelima. Jakarta: Erlangga.

Elkhani, N., \& Bakri, A. (2012). Review on "expectancy disconfirmation theory"(EDT) Model in B2C ECommerce. Journal of information systems research and innovation, 2(12), 95-102.

Najib, M., Widyastuti, H., Andrianto, M. S., Septiani, S., \& Fahma, F. (2020). Market Orientation and Service Quality as Driving Forces of Business Sustainability: Evidence from Small Coffee shop . Academy of Strategic Management Journal, 19(6), 1-8.

Nitecki, D. A., dan Hernon, P. 2000. Measuring Service Quality at Yale University's Libraries. Journal of Academic Librarianship. 26(4):259273

Nguyen, Q., Nisar, T.M., Knox, D. and Prabhakara, G.P. 2018. Understanding Costomer Satisfaction In The UK Quick Service Restauran Industry: The Influence of The Tangible Attribut of Preceived Service Quality. British Food Journal. Vol. 120. 6, pp.1207-1222

Pakurar, M., Haddad, H., Nagy, J., Popp, J., dan Olah, J. 2019. The service Quality Dimension That Affect Customer Satisfaction in The Jordanian Banking Sector. Sustainability (Switzerland). Vol. 11. 4, pp1-24

Parasuraman, A., Zeithaml, V. A., dan Berry, L. L. 1985. A Conceptual Model of Service Quality and Its Implication for Future Research. Journal of Retailing. 49(4):41-50

Parasuraman, A., Berry, L., \& Zeithaml, V. (2002). Refinement and reassessment of the SERVQUAL scale. Journal of retailing, 67(4), 114.
1988. Servqual a Multiple-item Scale for Measuring Consumer Perception of Service Quality. Journal of Retailing. 64(1):12-40

Petzer, D., dan Mackay, N. 2014. Dining Atmospherics and Food and Service Quality As Predictors Of Customer Satisfaction At Sit Down Restaurant. African Journal of Hospitality, Tourism and Leasure. 3(2):1-14

Poniman, A. S., dan Sentoso, S. 2015. Analisa Faktor yang Menjadi Preferensi Konsumen dalam Memilih Coffee shop di Surabaya. Jurnal Hospitality dan Manajemen Jasa. 1:45

Sajadi, R. E., dan Rizzuto, D. 2013. The Antecedents of Consumer Satisfaction and Loyalty in Fast Food Industry. International Journal of Quality and Reliability Management. 30(7):780-798

Sekaran, U. 2015. Metodologi Penelitian untuk Bisnis (Research Methods for Business). Jakarta: Salemba Empat

Shin, C., Hwang, G., Lee, H., dan Cho, S. 2015. The Impact of Korean Coffee shop Service Quality and Atmosphere on Customer Satisfaction and Loyalty. Journal of Bussiness Management. 5(4):47-57

Sugiyono. 2018. Metode Penelitian Kuantitatif. Bandung: Alfabeta

Suhud, U., Allan, M., Wibowo, S. F., Sabrna, E., dan Willson, G. 2020. Measurng Customer Satisfaction of a Café and Coffee shop Clony at a Tradisional Market. Journal of Food Service Businrss Research. 23.1. 7894

Spark, R. E., dan Legault, D. 2005. A Definition of Quality for Total Customer Satisfaction: The Bridge Between Manufacture and Customer. Sam Advance Management Journal. Winter:16-27 
Vanharanta, H., Kantola, J., \& Seikola, S. (2015). Customers' conscious experience in a coffee shop Procedia Manufacturing, 3, 618-625.

Wan, Y. K. 2013. Factor That Affect The Levels of Tourists Satisfaction and Loyalty Towards Food Festival: A Case Study of Macau. International Journal of Tourism Research. 15(3):226-240

Wisnalmawati. 2005. Pengaruh Persepsi Dimensi Kualitas Pelayanan Terhadap Niat Pembelian Ulang. Jurnal Ekonomi dan Bisnis. 10(3):153-165

Yusak T., Santoso, M., dan Hosea. E. 2013. Multi Dimensional Assessment for Residental Lighting Demand Side Management: A Proposal Framework. Applied Mechanics and Materials. 284-287:3612-3616 